\title{
AKTIVITAS ANTIMIKROBA EKSTRAK DAN FRAKSI TUNIKATA (Polycarpa aurata) YANG DIKOLEKSI DI SELAT LEMBEH, BITUNG TERHADAP Escherichia coli, Staphylococcus aureus DAN Candida albicans
}

\author{
Cinlye Juen Manoppo ${ }^{1)}$, Adithya Yudistira ${ }^{1)}$, Defny Silvia Wewengkang ${ }^{1)}$ \\ ${ }^{1)}$ Program Studi Farmasi, FMIPA UNSRAT, MANADO
}

\begin{abstract}
Tunicate is an invertebrate that lives in a coral reef ecosystem and produces many compounds such as, antibacterial, antitumor and anticancer. This study aimed to determine the antimicrobial activity of extracts and fraction of tunicate (Polycarpa aurata) collected in the Lembeh Strait, Bitung against Escherichia coli, Staphylococcus aureus and Candida albicans. Tunicate (Polycarpa aurata) was extracted by maceration method using 96\% ethanol solvent, fractination using liquid-liquid partition method with n-hexane, chloroform and methanol solvent, and antimicrobial testing using Kirby Bauer's disk diffusion method. The results showed that ethanol extract of tunicate (Polycarpa aurata) had antimicrobial activity againts Escherichia coli with an inhibition of $15.12 \mathrm{~mm}$, and againts Candida albicans with an inhibition of $15 \mathrm{~mm}$. While the methanol fraction showed antimicrobial with a strong category and inhibition of $16.17 \mathrm{~mm}$ againts Staphylococcus aureus.
\end{abstract}

Keyword: Tunicate (Polycarpa aurata), Extraction, Fractination, Antimicrobials

\begin{abstract}
ABSTRAK
Tunikata merupakan invertebrata di ekosistem terumbu karang yang banyak menghasilkan senyawa seperti, antibakteri, antitumor dan antikanker. Penelitian ini bertujuan untuk mengetahui aktivitas antimikroba ekstrak dan fraksi tunikata (Polycarpa aurata) yang dikoleksi di Selat lembeh, Bitung terhadap Escherichia coli, Staphylococcus aureus dan Candida albicans. Tunikata (Polycarpa aurata) diekstraksi menggunakan metode maserasi dengan pelarut etanol $96 \%$, fraksinasi menggunakan metode partisi dengan pelarut $n$-heksan, kloroform dan metanol, dan pengujian antimikroba menggunakan metode difusi agar Kirby Bauer. Hasil penelitian menunjukkan bahwa ekstrak etanol tunikata (Polycarpa aurata) memiliki aktivitas antimikroba kategori kuat pada fraksi metanol dengan daya hambat sebesar 16, $17 \mathrm{~mm}$ terhadap Escherichia coli, pada ekstrak etanol dengan daya hambat sebesar 15, $12 \mathrm{~mm}$ terhadap Staphylococcus aureus sedangkan pada Candida albicans aktivitas yang sangat baik terjadi pada ektraksi etanol sebesar $15 \mathrm{~mm}$.
\end{abstract}

Kata Kunci: Tunikata (Polycarpa aurata), Ekstraksi dan Fraksinasi, Antimikroba 


\section{PENDAHULUAN}

Hasil penelitian menunjukkan bahwa organisme laut memiliki potensi yang sangat besar, dalam menghasilkan senyawa-senyawa aktif yang dapat digunakan sebagai bahan baku obatobatan. Beberapa organisme laut yang diketahui dapat menghasilkan senyawa aktif antara lain ialah spons, moluska, bryozoa, tunikata dan lain-lain (Radjasa $e t$ al., 2011; Mans, 2016). Invertebrata laut menyediakan nutrient yang baik bagi berbagai mikroba (Erwin et al,. 2014).

Tunikata merupakan invertebrata di ekosistem terumbu karang yang banyak menghasilkan senyawa seperti, antibakteri, antitumor dan antikanker. Sekitar 1.000 bahan aktif telah diisolasi dari tunikata (Schmidt and Donia 2010). Salah satu komponen terumbu karang yang hidupnya sesil di terumbu, substrat dan batu adalah tunikata (Polycarpa aurata) (Lambert, 2010).

Penelitian yang telah dilakukan oleh Pham et al,. (2013) menunjukkan bahwa hasil ekstraksi tunikata (Polycarpa aurata) mengandung senyawa kimia berupa peptida dan golongan alkaloid yang bersifat sitotoksik dan memiliki kemampuan sebagai antibakteri terhadap beberapa bakteri patogen. Penelitian yang dilakukan oleh Christine (2015) dan Litaay dkk., (2015) menunjukkan bahwa isolat bakteri yang berasal dari tunikata (Polycarpa aurata) berpotensi menghasilkan senyawa antibakteri berifat bakteriosidal maupun bersifat bakteriostatis.

\section{METODOLOGI PENELITIAN}

Jenis penelitian ini merupakan penelitian eksperimental laboratorik. Alatalat yang digunakan dalam penelitian ini yaitu scuba diving (Peralatan Selam), ziplok, gunting, sarung tangan, botol air kemasan $600 \mathrm{~mL}$, pisau, telenan, corong pisah, corong gelas, wadah kaca, erlenmeyer, gelas ukur (Pyrex), gelas kimia (Pyrex), tabung reaksi, rak tabung reaksi, micro tubes, cawan petri, timbangan analitik, vortex (Benchmark), spatula, oven, pinset, batang pengaduk, pembakar spritus, pipet tetes, jarum ose, vial, lemari pendingin, incubator incucell (N-Biotek), laminary air flow (Clean Bench), autoklaf (autoklaf KT-30s), mikropipet, jangka sorong, digital caliper, jas laboratorium dan kamera. Bahanbahan yang digunakan pada penelitian ini yaitu Tunikata Polycarpa aurata, Staphylococcus aureus, Escherichia coli, Candida albicans, aquades, etanol, nheksan, kloroform, metanol, pepton, ekstrak daging (meat extract), natrium klorida, nutrient agar, kloramfenikol (paper disc), kertas label, spidol permanen, kertas saring, kapas, aluminium foil dan tissue.

\section{Prosedur Penelitian}

\section{Pembuatan Ekstrak}

Ekstrak tunikata (Polycarpa aurata) $530 \mathrm{~g}$ dibuat dengan cara maserasi sebanyak 3 kali. Sampel yang sudah dipotomg kecil-kecil dimasukan kedalam botol lalu direndam dengan larutan etanol 96\% selama 1x24 jam. Kemudian sampel disaring menggunakan kertas saring menghasilkan filtrat 1 dan debris 1 . Debris 1 kemudian ditambah dengan larutan etanol lalu ditutup dengan aluminium foil dan dibiarkan selama 1×24 jam, sampel tersebut disaring menggunakan kertas saring menghasilkan filtrat 2 dan debris 2 . Debris 2 kemudian ditambah dengan larutan etanol lalu ditutup dengan aluminium foil selama $1 \times 24$ jam, sampel tersebut di lalu disaring menggunakan 
kertas saring menghasilkan filtrat 3 dan debris 3. Filtrat 1, 2, dan 3 dicampur menjadi satu kemudian disaring, lalu diuapkan menggunakan oven hingga diperoleh ekstrak kental etanol.

\section{Pembuatan Fraksi}

Ekstrak kental etanol tunikata (Polycarpa aurata) sebanyak $1,00 \mathrm{~g}$ dimasukkan dalam Erlenmeyer, dilarutkan dengan campuran metanol : air $(\mathrm{MeOH}$ : $\mathrm{H}_{2} \mathrm{O}$ ) (80:20) sebanyak $100 \mathrm{~mL}$. Setelah sampel larut, dimasukkan kedalam corong pisah lalu ditambahkan pelarut n-heksan dengan jumlah yang sama, setelah itu dikocok berulangkali sampai homogen. Dibiarkan sampel sampai terbentuk lapisan metanol : air $\left(\mathrm{MeOH}: \mathrm{H}_{2} \mathrm{O}\right)$ dan $\mathrm{n}$ heksan. Masing - masing lapisan ditampung dalam wadah yang berbeda. Lapisan n- heksan dievaporasi menggunakan Oven hingga kering, lalu ditimbang dengan timbangan analitik dan diperoleh fraksi n-heksan $0,1 \mathrm{~g}$.

Lapisan $\mathrm{MeOH}: \mathrm{H}_{2} \mathrm{O}$ ditambahkan akuades sebanyak $100 \mathrm{~mL}$ dipartisi dengan pelarut kloroform dengan perbandingan 1:1 v/v dalam corong pisah, lalu dikocok berulangkali sampai homogen. Dibiarkan sampai terbentuk dua lapisan yaitu lapisan $\mathrm{MeOH}$ dan kloroform. Masing - masing lapisan ditampung dalam wadah yang berbeda. Lapisan kloroform dievaporasi menggunakan Oven hingga kering lalu ditimbang dan diperoleh fraksi kloroform 0,28 g. Lapisan $\mathrm{MeOH}$ yang ditampung pada wadah yang lain dievaporasi menggunakan Oven hingga kering lalu ditimbang berat sampel, dan diperoleh fraksi $\mathrm{MeOH}$ 0,51 g. Rendemen-rendemen fraksi dihitung dengan persamaan sebagai berikut :

$$
\text { Rendemen }=\frac{\text { Berat hasil ekstrak }}{\text { Berat ekstraksi awal }} \times 100 \%
$$

\section{Pembuatan Media Cair B1}

Ditimbang Pepton 0,5 g, ekstrak daging 0,3 g (meat extract) , Natrium klorida 0,3 g dilarutkan dalam akuades sebanyak $100 \mathrm{~mL}$ menggunakan Erlenmeyer, dikocok sampai homogen. Media yang telah homogen kemudian disterilkan dengan menggunakan autoklaf pada suhu $121^{\circ} \mathrm{C}$ selama 15 menit. Dipipet $1 \mathrm{~mL}$ media cair B1, kemudian masukkan dalam tabung reaksi dan tutup dengan aluminium foil. Media cair B1 siap digunakan sebagai media kultur mikroba (Ortez, 2005).

\section{Kultur Mikroba}

Mikroba yang sudah dikultur (Escherichia coli, Staphylococcus aureus dan Candida albicans) ditambahkan media cair B1 yang disiapkan sebelumnya sebanyak $100 \mu \mathrm{L}$ kedalam tabung reaksi yang berbeda - beda. Masing - masing tabung reaksi ditutup dengan aluminium foil dan dimasukkan kedalam incubator selama 1x24 jam dengan suhu $37^{\circ} \mathrm{C}$.

\section{Pembuatan Media Agar B1}

Pepton $0,5 \mathrm{~g}$, ekstrak daging (meat extract) $0,3 \mathrm{~g}$, natrium klorida $0,3 \mathrm{~g}$, agar 1,5 $\mathrm{g}$ dan dilarutkan dalam akuades sebanyak $100 \mathrm{~mL}$ menggunakan Erlenmeyer, dikocok sampai homogen. Media yang telah homogen kemudian disterilkan dengan menggunakan autoklaf pada suhu $121{ }^{\circ} \mathrm{C}$ selama 15 menit. Media agar B1 siap digunakan untuk uji aktivitas antimikroba.

\section{Pembuatan Kontrol Positif dan Kontol Negatif}

Kontrol positif dalam pengujian antimikroba ini menggunakan kloramfenikol paper disc. Kontrol negatif yang digunakan dalam penelitian ini yaitu 
menggunakan pelarut methanol, dengan cara membuat larutan stok metanol dengan mengambil sebanyak $200 \mu \mathrm{L}$ metanol kemudian ditotolkan pada kertas cakram.

\section{Pembuatan Larutan Uji}

Larutan uji dibuat dengan cara melarutkan ekstrak etanol tunikata (Polycarpa aurata) sebanyak $1 \mathrm{mg}$ kedalam $200 \quad \mu \mathrm{L}$ metanol sehingga menghasilkan konsentrasi larutan uji sebanyak $250 \mu \mathrm{g} / 50 \mu \mathrm{L}$. Perlakuan yang sama dilakukan untuk fraksi n-heksan, fraksi kloroform dan fraksi metanol (Ortez,2005).

\section{Pengujian Aktivitas Antimikroba}

Metode yang digunakan dalam penelitian ini yaitu metode difusi agar (disc diffusion Kirby and Bauer). Aktivitas ini diuji pada mikroorganisme Escherichia coli, Staphylococcus aureus dan Candida albicans. Pada pengujian aktivitas antibakteri ini, kertas cakram (paper disc) yang digunakan berukuran 6 mm dengan daya serap $50 \mu \mathrm{L}$ tiap cakram. Kosentrasi yang digunakan pada pengujian ini hanya satu kosentrasi yaitu $250 \mu \mathrm{g} / 50 \mu \mathrm{L}$ pada setiap sampel yang terdiri dari ekstrak kental, fraksi n-heksan, fraksi kloroform, fraksi metanol-air, kontrol positif dan kontrol negatif. Sampel yang telah ditentukan kosentrasinya $250 \mu \mathrm{g} / 50 \mu \mathrm{L}$ ditotolkan pada masingmasing cakram dengan menggunakan mikropipet.

Untuk media agar B1 yang sudah diautoklaf pada suhu $121{ }^{\circ} \mathrm{C}$ selama 15 menit, kemudian dinginkan sampai suhu $40{ }^{\circ} \mathrm{C}$. Tuangkan media agar ke cawan petri, Ambil sebanyak $100 \mu \mathrm{L}$ mikroba yang telah di kultur dalam tabung reaksi, dipipet dan diinokulasi pada media agar dan tunggu sampai media agar mengeras.
Masing-masing cawan petri diberi label dan nomor sampel yang sesuai. Letakkan kertas cakram yang telah ditotolkan sampel uji tunikata (Polycarpa aurata). Cawan petri lalu diinkubasi selama $1 \times 24$ jam pada suhu $37^{\circ} \mathrm{C}$ (Ortez, 2005).

\section{Pengamatan dan Pengukuran Zona Bening}

Pengamatan dilakukan dengan mengukur diameter zona hambat yang terjadi pada media dengan menggunakan jangka sorong beralaskan kertas berwarna gelap. Diameter zona hambat yang diukur yaitu daerah jernih yang terbentuk disekitar disk/cakram (tidak ada pertumbuhan bakteri) diukur dari ujung yang satu ke ujung yang lain melalui tengah-tengah disk/cakram atau diukur diameter vertikal dan horizontalnya (Soemarno,2000). Diameter zona hambat diukur dalam satuan millimeter $(\mathrm{mm})$ menggunakkan mistar berskala (Davis and Stoud, 1971) dengan sedikit modifikasi.

\section{HASIL DAN PEMBAHASAN}

\section{Ekstrak tunikata (Polycarpa aurata)}

Ekstraksi adalah proses pemisahan zat dari campurannya dengan menggunakan pelarut tertentu. Ekstraksi terdiri dari beberapa metode di antaranya yaitu metode maserasi. Maserasi merupakan metode ekstraksi sederhana yang sering digunakan (Mukhriani, 2014). Proses maserasi ini dilakukan dengan cara merendam sampel tunikata (Polycarpa aurata) sebanyak 3×24 jam dengan menggunakan larutan etanol $96 \%$. Sebelum maserasi dilakukan, sampel di bersihkan dari kotoran dan dipotong kecilkecil. Pemotongan sampel dilakukan untuk memperluas permukaan sentuh sampel, karena luas permukaan berpengaruh terhadap hasil yang optimal dari proses 
maserasi. Semakin kecil ukuran sampel maka semakin besar luas permukaannya sehingga memudahkan senyawa aktif yang ada pada tunikata (Polycarpa aurata) dapat larut ke dalam pelarut yang digunakan. Pelarut yang digunakan dalam penelitian ini yaitu pelarut etanol $96 \%$. Menurut Trifani (2012), etanol digunakan sebagai pelarut karena bersifat polar, universal, dan mudah didapat.

\section{Fraksi tunikata ( Polycarpa aurata)}

Fraksinasi adalah proses penarikan suatu senyawa dengan menggunakan beberapa pelarut yang tidak saling bercampur. Senyawa-senyawa yang bersifat non polar akan larut dalam pelarut yang nonpolar sedangkan senyawasenyawa yang bersifat polar akan larut dalam pelarut yang bersifat polar (Sari, 2012). Pelarut yang digunakan untuk fraksinasi yaitu n-heksan, kloroform, dan metanol. Pelarut n-heksan digunakan untuk menarik senyawa yang bersifat non polar, pelarut kloroform digunakan untuk menarik senyawa yang bersifat semi polar sedangkan pelarut metanol digunakan untuk menarik senyawa-senyawa yang bersifat polar.

Tabel 2. Rendemen ekstrak dan fraksi tunikata (Polycarpa aurata)

\begin{tabular}{cccc}
\hline No & Sampel & Rendemen (\%) & Warna Sampel \\
\hline $\mathbf{1}$ & Ekstrak Etanol & 0,47 & Coklat kemerahan \\
$\mathbf{2}$ & Fraksi n-Heksan & 10 & Bening \\
$\mathbf{3}$ & Fraksi Kloroform & 2,8 & Coklat Pekat \\
$\mathbf{4}$ & Fraksi Metanol & 5,1 & Kuning Kecoklatan \\
\hline
\end{tabular}

Menurut Nuhayati et al., (2009) bahwa nilai rendemen yang tinggi menunjukan banyaknya komponen bioaktif yang terkandung didalamnya. Nilai rendemen yang paling tinggi adalah rendemen yang menggunakan pelarut metanol, sehingga memungkinkan bahwa senyawa bioaktif yang terkandung dalam tunikata (Polycarpa aurata) lebih bersifat polar. Jenis pelarut menghasilkan rendemen yang berbeda karena Semakin tinggih rendemen yang dihasilkan maka semakin tinngih pula komponen bioaktif yang terkandung dalam tunikata (Polycarpa aurata).

\section{Aktivitas antimikroba ekstrak dan fraksi tunikata (Polycarpa aurata)}

Uji aktivitas antimikroba ekstrak dan Fraksi n-heksan, fraksi kloroform dan fraksi metanol tunikata (Polycarpa aurata) terhadap bakteri Escherichia coli, Staphylococcus aureus dan Candida albicans dengan metode difusi agar (Difusi Kirby-Bauer) yang telah dimodifikasi. Berikut adalah hasil pengukuran aktivitas antimikroba ekstrak dan Fraksi n-heksan, fraksi kloroform dan fraksi metanol tunikata (Polycarpa aurata) terhadap bakteri Escherichia coli, Staphylococcus aureus dan Candida albicans. 
Tabel 3. Hasil pengukuran diameter zona hambat ekstrak dan fraksi tunikata (Polycarpa aurata) terhadap Escherichia coli.

\begin{tabular}{ccccccc}
\hline Ulangan & \multicolumn{5}{c}{ Diameter zona hambat $(\mathbf{m m})$ terhadap Escherichia coli } \\
\cline { 2 - 6 } & $\begin{array}{c}\text { Ekstrak } \\
\text { EtOH }\end{array}$ & $\begin{array}{c}\text { Fraksi } \\
\text { n-Heksan }\end{array}$ & $\begin{array}{c}\text { Fraksi } \\
\mathrm{CHCl}_{3}\end{array}$ & $\begin{array}{c}\text { Fraksi } \\
\mathrm{MeOH}\end{array}$ & $\begin{array}{c}\text { Kontrol } \\
(+)\end{array}$ & $\begin{array}{c}\text { Kontrol } \\
(-)\end{array}$ \\
I & 13,53 & - & 9,54 & 16,94 & & \\
II & 13,10 & - & 10,10 & 15,78 & & \\
III & 12,39 & - & 7,44 & 15,78 & 29,77 & - \\
Total & 39,02 & - & 27,08 & 48,50 & & \\
$\overline{\boldsymbol{X}}$ & 13,70 & - & 9,03 & 16,17 & & \\
\hline
\end{tabular}

Tabel 4. Hasil pengukuran diameter zona hambat ekstrak dan fraksi tunikata (Polycarpa aurata) terhadap Staphylococcus aureus.

\begin{tabular}{|c|c|c|c|c|c|c|}
\hline \multirow[t]{2}{*}{ Ulangan } & \multicolumn{6}{|c|}{ Diameter zona hambat (mm) terhadap Staphylococcus aureus } \\
\hline & $\begin{array}{c}\text { Ekstrak } \\
\text { EtOH }\end{array}$ & $\begin{array}{c}\text { Fraksi } \\
\text { n-Heksan }\end{array}$ & $\begin{array}{l}\text { Fraksi } \\
\mathrm{CHCl}_{3}\end{array}$ & $\begin{array}{l}\text { Fraksi } \\
\mathrm{MeOH}\end{array}$ & $\begin{array}{c}\text { Kontrol } \\
(+)\end{array}$ & $\begin{array}{c}\text { Kontrol } \\
(-)\end{array}$ \\
\hline $\mathbf{I}$ & 14,06 & - & 11,17 & 10,53 & & \\
\hline II & 15,06 & - & 11,76 & 14,28 & & \\
\hline III & 16,25 & - & 11,27 & 10,70 & 18,06 & - \\
\hline Total & 45,37 & - & 34,20 & 35,51 & & \\
\hline $\bar{X}$ & 15,12 & - & 11,40 & 11,83 & & \\
\hline
\end{tabular}

Tabel 5. Hasil pengukuran diameter zona hambat ekstrak dan fraksi tunikata (Polycarpa aurata) terhadap Candida albicans.

\begin{tabular}{|c|c|c|c|c|c|c|}
\hline \multirow[t]{2}{*}{ Ulangan } & \multicolumn{6}{|c|}{ Diameter zona hambat $(\mathrm{mm})$ terhadap Candida albicans } \\
\hline & $\begin{array}{c}\text { Ekstrak } \\
\text { EtOH }\end{array}$ & $\begin{array}{c}\text { Fraksi } \\
\text { n-Heksan }\end{array}$ & $\begin{array}{l}\text { Fraksi } \\
\mathrm{CHCl}_{3}\end{array}$ & $\begin{array}{l}\text { Fraksi } \\
\mathrm{MeOH}\end{array}$ & $\begin{array}{c}\text { Kontrol } \\
(+)\end{array}$ & $\begin{array}{c}\text { Kontrol } \\
(-)\end{array}$ \\
\hline I & 15 & - & 8 & 12 & & \\
\hline II & 15 & - & 8 & 12 & & \\
\hline III & 15 & - & 8 & 12 & 19 & - \\
\hline Total & 45 & - & 24 & 36 & & \\
\hline$\overline{\boldsymbol{X}}$ & 15 & - & 8 & 12 & & \\
\hline
\end{tabular}

Berdasarkan hasil pengamatan
yang dilakukan terhadap mikroba
Escherichia coli, Staphylococcus aureus
dan Candida albicans masing-masing
sebanyak tiga kali pengulangan

memperlihatkan adanya zona hambat yang terbentuk disekitar disk/cakram kecuali pada fraksi n-heksan. Pada fraksi n-heksan tidak menunjukan adanya aktivitas antimikroba yang terbentuk, ini berarti 
tidak ada kandungan senyawa antimikroba yang bersifat non polar pada sampel uji tunikata (Polycarpa aurata), sedangkan pada ekstrak etanol memperlihatkan adanya aktivitas antimikroba terhadap Escherichia coli, Staphylococcus aureus dan Candida albicans. Hal ini ditunjukan dengan terbentuknya zona hambat disekitar cakram sebesar 13,70 mm pada Escherichia coli tergolong kuat, 15,12 mm pada Staphylococcus aureus tergolong kuat dan $15 \mathrm{~mm}$ pada Candida albicans tergolong kuat. Hasil ini menunjukan bahwa fraksi metanol memiliki aktivitas sebagai antimikroba. Pada fraksi metanol memperlihatkan aktivitas antimikroba terhadap Escherichia coli, Staphylococcus aureus dan Candida albicans yang tergolong kuat. Hal ini ditunjukan dengan terbentuknya zona hambat disekitar cakram sebesar $16,17 \mathrm{~mm}$ pada Escherichia coli, $11,83 \mathrm{~mm}$ pada Staphylococcus aureus dan $12 \mathrm{~mm}$ pada Candida albicans. Jika dibandingkan dengan ekstrak etanol dan fraksi metanol, fraksi kloroform memperlihatkan daya hambat yang lebih rendah. Hal ini ditunjukan dengan aktivitas antimikroba sebesar 9,03 mm pada Escherichia coli tergolong sedang, $11,40 \mathrm{~mm}$ pada Staphylococcus aureus tergolong kuat dan $8 \mathrm{~mm}$ pada Candida albicans tergolong sedang.

Hasil pengukuran diameter zona hambat digolongkan berdasarkan klasifikasi zona hambat menurut Davis and Stout (Tabel 1). Ekstrak etanol dan fraksi metanol merupakan ekstrak dan fraksi yang efektif terhadap mikroba Escherichia coli dan Candida albicans karena memiliki daya hambat mikroba yang kuat, hal ini dikarenakan gram negatif cenderung peka terhadap antimikroba yang bersifat polar. sedangkan pada ekstrak etanol, fraksi kloroform dan fraksi metanol terhadap bakteri Staphylococcus aureus memiliki kemampuan menghambat mikroba dengan kategori kuat. Hal ini menerangkan bahwa bakteri gram positif lebih peka dibandingkan dengan bakteri gram negatif. Penelitian mengenai aktivitas antibakteri dan karakteristik gugus fungsi dari tunikata (Polycarpa aurata) yang dilakukan oleh Kumayas dkk., (2015) menyatakan bahwa gram positif lebih sensitif terhadap antibakteri karena struktur dinding sel yang sederhana sehingga mempermudah senyawa antibakteri masuk kedalam sel sedangkan struktur dinding sel gram negatif lebih kompleks.

Kontrol positif memperlihatkan aktivitas antimikroba yang paling besar terhadap mikroba Escherichia coli, Staphylococcus aureus dan Candida albicans. Kontrol positif yang digunakan yaitu Kloramfenikol. Kloramfenikol merupakan antibiotik yang memiliki spekrum luas terhadap bakteri (Katzung, 2004). Kontrol negatif tidak menunjukan terbentuknya zona hambat. Hal tersebut menandakan bahwa tidak ada pengaruh kontrol negatif terhadap antimikroba yang diuji. Kontrol negatif yang digunakan yaitu metanol.

Aktivitas antikiroba yang terbentuk disekitar disk/cakram ini disebabkan oleh aktivitas senyawa yang terkandung dalam ekstrak dan fraksi Tunikata (Polycarpa aurata). Semakin besar zona hambat yang terbentuk maka semakin kuat senyawa yang terkandung dalam tunikata (Polycarpa aurata) untuk menghambat pertumbuhan mikroba. 


\section{DAFTAR PUSTAKA}

Christine, G. 2015. Potensi Tunikata Polycarpa aurata Sebagai Sumber Inokulum Bakteri Endosimbion Penghasil Antibakteri. [Skripsi]. Universitas Hasanuddin, Makassar.

Davis, W.W and Stout, T.R. 1971. Disc Plate Methods of Microbiological Antibiotic Assay. Microbiology. 22(4): 659-665.

Erwin, P. M., M. C. Pineda, N.Webster, X.Truon, S. López-Legentil. 2014. Down under the tunic: bacterial biodiversity hotspots and widespread ammoniaoxidizing archaea in coral reef ascidians. ISME J. 8: 575-588.

Katzung, B. G,. 2004. Farmakologi Dasar dan Klinik. Edisi XIII. Buku 3. Translation of Basic and Clinical Pharmacology Eight Edition. Alih Bahasa oleh Bagian Farmakologi Fakultas Kedokteran Universitas Airlangga. Salemba Medika, Jakarta.

Kumayas, A.R., D. S. Wewengkang., dan S. Sudewi. 2015. Aktifitas Antibakteri Dan Karateristik Gugus Fungsi Dari Tunikata Polycarpa Aurata. Jurnal Ilmiah Farmasi. Vol. 4(1).

Lambert, G., Shenkar, N., \& Swalla, B,.J. 2010. First Pacific record of the north Atlantic ascidian Molgula citrina-bioinvasion or circumpolar distribution. Aquatic Invasions. 5(4): 369-378.
Litaay, M, G. Christine, R.G. B, Z.Dwyana. 2015. Bioaktivitas simbion tunikata Polycarpa aurata sebagai antimikroba. Prosiding Semnas PBI ke 23. Jayapura, September 2015.

Mans, D.R.A. 2016. Exploring the global animal biodiversity in the search for new drugs - marine invertebrates. J Transl Sci. 2(3): 170-179. doi: 10.15761/ JTS. 1000136 .

Muhkriani. 2014. Ekstraksi, Pemisahan Senyawa dan Identifikasi Senyawa Aktif. Makassar: Jurnal Kesehatan.7 (2) : 361-7

Nurhayati, T, D. Aryanti, dan Nurjanah. 2009. Kajian Awal Potensi Ekstrak Spons Sebagai Antioksidan. Jurnal Kelautan Nasional. 2(2):43-51.

Ortez, J.H. 2005. Disk Diffusion testing in manual of antimicrobial susceptibility testing. Marie B. Coyle (Coord. Ed). American society for Microbiology.

Pham, C. D., H., Weber, R., Hartmann, V., Wray, W., Lin, D., Lai, and P. Proksch. 2013. New Cytotoxic 1,2,4-Thiadiazole Alkaloids from the Tunikata $P$. aurata. Org. Lett. 15

(9):2230-2233. http://www.pubfacts.com.

Radjasa, O.K., Y.M. Vaske, G. Navarro, H.C. Vervoort, K.Tenney, R.G. Linington, P. Crews. 2011. Highlights of marine invertebratederived biosynthetic products: Their biomedical potential and possible production by microbial 
PHARMACON-PROGRAM STUDI FARMASI, FMIPA, UNIVERSITAS SAM RATULANGI,

Volume 8 Nomor 1 Februari 2019

associants. Bioorganic \& Medicinal Chemistry. 19: 66586674.

Sari, Cahyo IP. 2012. Kualitas Minuman Serbuk Kersen (Muntingia calabura L.) dengan Variasi Konsentrasi Maltodekstrin dan Ekstraksi Kayu Secang (Caesalpinia sappan L.). SKRIPSI. Fakultas Teknobiologi Universitas Atma Jaya Yogyakarta, Yogyakarta.
Schmidt, E. W and M. S. Donia. 2010. Life in cellulose houses: Symbiotic bacterial biosynthesis of ascidian drugs and drug leads. Curr. Opin. Biotechnol. 21: 827-833.

Soemarno. 2000. Depertemen Kesehatan Republik Indonesia Isolasi Dan Identifikasi Bakteri Klinik. Akademi Analisis Kesehatan Yogyakarta.. Yogyakarta.

Trifani. 2012. Ekstraksi Pelarut Cair-Cair. http://awjee. Diakses pada tanggal $10 \quad$ Oktober 2018. 